\title{
Chapter 5 \\ Sanctuary Cities and Covid-19: The Case of Canada
}

\author{
Mireille Paquet, Noémie Benoit, Idil Atak, Meghan Joy, Graham Hudson, \\ and John Shields
}

\subsection{Introduction}

Amidst record migration numbers, a growing displacement crisis, and rapid changes in national immigration programmes, non-status individuals and those with precarious immigration status are in growing number globally. As with administrative immigration categories, states vary when it comes to the labels used to identify these populations and in their practices of counting them. In Canada, governments do not publish official approximations of the size of this population. Indeed, the International Organization for Migration concludes that 'Canada [...] has a significant number of irregular migrants, although estimates vary widely, and accurate numbers are difficult to establish' (International Organization for Migration, 2019, 112). This population includes irregular migrants, individuals who overstayed their visa, committed offences affecting their status, or refused refugee claimants as well as individuals who lost status due to changes in government policies or actions by

\author{
M. Paquet $(\bowtie)$ \\ Department of Political Science, Concordia University, Montreal, Canada \\ e-mail: mireille.paquet@concordia.ca \\ N. Benoit \\ Political Science, Concordia University, Montreal, Canada \\ I. Atak \\ Department of Criminology \& Director of Criminology and Social Justice MA Program, \\ Ryerson University, Toronto, Canada \\ M. Joy \\ Department of Political Science, Concordia University, Montreal, Canada \\ G. Hudson \\ Faculty of Law, Ryerson University, Toronto, Canada \\ J. Shields \\ Department of Politics and Public Administration, Ryerson University, Toronto, Canada
}

(C) The Author(s) 2022

A. Triandafyllidou (ed.), Migration and Pandemics, IMISCOE Research Series,

https://doi.org/10.1007/978-3-030-81210-2_5 
their sponsors (e.g. spouses, family members, employers). Despite Canada's heavily controlled immigration regime, policy changes and current outcomes - including an increased reliance on temporary work permits, a quicker pace in policy reforms, and growing delays in the treatment of refugee protection claims - also generated more precarity when it comes to immigration status (Goldring et al., 2009; Goldring \& Landolt, 2013; Hari, 2014; Paquet \& Larios, 2018; Tungohan et al., 2015).

As with other migrants, non-status migrants and those living with precarious status (e.g. students, those on temporary visas and individuals who are depending on employers or relatives to keep their status) tend to settle in urban centres. As a result, cities have become spaces of policy innovation on how to address the needs of these populations. City services are increasingly called upon to function as first responders for migrants' well-being and play a key part in how migrants settle and integrate into society (Provine \& Varsanyi, 2012; Varsanyi et al., 2012). Sanctuary policies are one of these innovative responses (Bauder, 2017). Highly variegated across countries and cities, these policies generally aim at providing services to individuals without accounting for immigration status and at limiting cooperation with immigration enforcement agencies. In Canada, seven municipalities have enacted such policies since 2013: Toronto, Hamilton, Vancouver, Ajax, Montreal, Edmonton, and London. These relatively novel policies emerged as a result of activism and government social learning.

Urban centres have been especially hit by the Covid-19 pandemic and this public health crisis has generated particular risks for non-status and precarious migrants (Bauder \& Godoy, 2020). What are the risks faced by these populations and have they been addressed by sanctuary policies? More broadly, is there a future for Canadian sanctuary policies in the post-Covid-19 recovery? Using existing research on the topic and content-related evidence, we highlight the complex position of cities in responding to public health emergencies in multi-level settings, while pointing again to the limited capacities of Canadian cities in providing true sanctuary for immigrants without status. We show that the non-status and precarious migrants in Canada faced specific risks during the pandemic and that current municipal sanctuary policies should be boosted to respond to the particular vulnerabilities of these populations. More broadly, this chapter identifies the obstacles and opportunities for the maintenance and expansion of rights for all by Canadian city governments during and after periods of 'crisis', such as this pandemic.

\subsection{Sanctuary Cities}

Globally, sanctuary city policies are an expression of municipalities' claim for an extended responsibility in how migrants are received and treated. They also build on the activism of a diverse sanctuary movement aimed at creating cultures of hospitality, at empowering non-status migrants (Moffette \& Ridgley, 2018; Ridgley, 2008), and at challenging the legitimacy of national borders as well as associated immigration enforcement. Central to both sanctuary policies and activism is the idea that, as 
a matter of justice and for the greater good of the city, all residents should have access to fundamental rights and services, regardless of their immigration status. They advance the principle that the mere fact of residing in a city entitles inhabitants to certain rights and services.

The 'sanctuary city' concept refers to different policies and practices and focuses on variable populations in different national contexts (Bauder, 2017). Sanctuary cities in Canada and the United States seek to protect specifically non-status migrants by allowing them to access some municipal programmes and services without fear of being arrested, detained, and removed from the country. ${ }^{1}$ To do so, these policies usually include a 'don't ask, don't tell' approach whereby the city does not require government workers to ask about an individual's immigration status and commits not to share any personal information pertaining to immigration status with other agencies (Paquet, 2017). As part of these policies, cities also experiment with the issuance of identification documents - such as municipal IDs - that allow individuals to engage with local public institutions (e.g. libraries or transit authorities) and to facilitate the conduct of daily activities such as banking or signing a lease (de Graauw, 2014). Sanctuary policies, especially in the US include official commitment of non-cooperation with immigration enforcement authorities. In this case, police forces and municipal bodies refuse to enter into formal agreements that devolve enforcement to them, resist political pressure to engage in indirect migration control practices, and strongly limit the sharing of information on residents with enforcement agencies (Hershkowitz et al., 2020; Ridgley, 2008).

Sanctuary policies are not only occurring in the US. Other similar policies are found in European cities; however, these cities possess far less autonomy on policing matters, limiting their potential regarding law enforcement (Morris, 2020). Urban sanctuary initiatives in the United Kingdom, for instance, do not seek to create legal shelters from authorities, but rather to transform the public discourse on refugees. The goals of British legal sanctuary policies are therefore more discursive, attempting to disrupt the distinction between guests and hosts, to foster a culture of hospitality, and to consequently encourage undocumented migrants to participate as active citizens in their urban community (Bauder, 2017). In other European countries, however, the term 'sanctuary' is rarely used due to its religious connotation (Bauder \& Gonzalez, 2018). Nevertheless, other solidarity-based policies emerged, named otherwise, such as the Barcelona Refugee City Plan in 2015, which reacted to the Spanish government's restrictive policies towards refugees by channelling urban solidarity and coordinating to offer programmes of support (Agustín \& Jørgensen, 2019). Moreover, in the Netherlands, the Amsterdam-Zuid Oost policy allows for victims and witnesses of crimes without status to enter police stations

\footnotetext{
${ }^{1}$ In most European countries, cities of sanctuary involve a general commitment to welcoming asylum seekers and refugees. For instance, the UK-based City of Sanctuary movement that emerged with the support of the City Council and local organizations in Sheffield in 2007 aims to exemplify hospitality toward an empowerment of asylum seekers and more precisely to 'influence policy-makers and public attitudes throughout the country' in order 'to build a culture of hospitality for people seeking sanctuary' (Bagelman, 2013, 49).
} 
under the assurance that they will be able to leave without facing arrest (Morris, 2020). Berlin, on its part, provides an anonymous health-insurance card, while Zurich dispenses legal identity cards to all its citizens regardless of status (Bauder \& Weisser, 2019).

Research on sanctuary cities has made a strong normative case and demonstrated empirically that these policies have effects on identity formation, leading to migrants developing feelings of belonging and new forms of urban citizenship (e.g. Nyers, 2010; Young, 2011, 2012). According to Nail et al., for instance, Canadian sanctuary cities 'disrupt the distinctions caused by federal status categories' to 'forge a unifying identity among all residents of the city' (2010, 151). In political science and urban studies, research has also verified the claims, made by politicians, that sanctuary policies could lead to decreased policing and rises in criminality in urban areas. While no such study has been conducted in Canada, American studies have confirmed that municipal sanctuary policies have either no impact on crime or, in some cases, decrease crime (Martínez et al., 2018; O’Brien et al., 2019; Wong, 2017). In addition, these policies contribute to efforts by local governments to challenge national policies that affect their residing immigrant populations. In its simplest form, this challenge is symbolic: while these residents have not received explicit consent from the nation-state to enter and remain within the state, they are receiving consent to remain in the cities which are enacting these local policies (Varsanyi, 2006, 240). Increasingly, however, legal challenges associated with sanctuary policies provide opportunities to test the jurisdictional space and legal capacities of cities.

\subsection{Sanctuary Cities in Canada}

Like in many American states and cities, the sanctuary practices in Canada involved churches and communities harbouring in a physical shelter migrants at risk of detention and deportation (Lippert, 2004). These early sanctuary practices denounced federal decisions deemed unfair toward precarious migrants. They were adopted in a context where local anti-poverty advocates identified immigration status barriers as a rising concern for addressing poverty (Atak, 2019; Hudson et al., 2017). McDonald $(2009,67)$ explains how, from 1994 to 1998, these movements led the government to regularise several thousand failed refugee claimants from moratorium countries, such as China, Iran, and Algeria who were generally stuck in limbo. However, despite these early successes, there have not been any such regularisation programmes since 2004. In Toronto, as Bauder notes, 'the campaign to become a sanctuary city was spearheaded by the Solidarity City Network, which included a range of community organizations and advocacy groups' (Hannan \& Bauder, 2015, 10). In Montreal, self-organised 'action committees' of non-status migrants and refugees have emerged and asserted themselves as political by organising against detentions and deportations (Atak, forthcoming; Nyers, 2010). Solidarity Across Borders and other groups organised public campaigns against 
detentions and deportations of non-status migrants. Organisations have been working to build a support network amongst them. They have pressured the Federal government to regularise non-status migrants (Lowry \& Nyers, 2013). Debates on access to education and healthcare have helped to frame the topic as a social justice issue and sensitise the public and authorities to the plight of this population.

Around the 2010s, some local governments in Canada started to take action in the face of unfair treatment and socioeconomic marginalisation of non-status residents. In 2013, Toronto became the first 'sanctuary city' in Canada to enable all residents to access municipal services. As Table 5.1 lists, other Canadian cities followed suit. By 2019, seven Canadian cities had official sanctuary or access without fear policies. These cities are located in different regions of Canada and are of very different sizes. These cities diverge when it comes to their total immigrant population and the rate of arrivals of newcomers.

Canadian sanctuary policies vary in their scope but have three important characteristics in common. First, they share the objective of providing that all residents have access to municipal services (Paquet et al., 2019). In Toronto, the policy is justified as a tool to 'Ensur[e] that Torontonians, regardless of immigration status, have access to City services without fear of being asked for proof of status' (Toronto, 2015). The City of London similarly states that 'The purpose of [its] policy is to enable London residents with uncertain or no immigration status to access City services without fear that the City will ask for and provide information on the immigration status of individuals to other public institutions or orders of government' (City of London, 2018). These services are numerous and rest on the specific responsibilities of cities in the Canadian jurisdictional architecture. Generally, Canadian cities - which include municipal governments and special purpose bodies governing a service funded by municipal governments - have responsibility over the built environment, including urban planning, roads, public transit, and waste

Table 5.1 Canadian local sanctuary policies

\begin{tabular}{l|l|l|l|l}
\hline City & Province & Year & Policy name & $\begin{array}{l}\text { Total } \\
\text { population } \\
(2019)\end{array}$ \\
\hline Toronto & Ontario & 2013 & Access Toronto & $6,471,850$ \\
\hline Hamilton & Ontario & 2014 & $\begin{array}{l}\text { Access to services for undocumented } \\
\text { individuals }\end{array}$ & 794,716 \\
\hline Vancouver & $\begin{array}{l}\text { British } \\
\text { Columbia }\end{array}$ & 2016 & $\begin{array}{l}\text { Access to city services without fear for } \\
\text { residents with uncertain or no immigration } \\
\text { status }\end{array}$ & $2,691,351$ \\
\hline Ajax & Ontario & 2017 & No official title & N.D. ${ }^{\text {a }}$ \\
\hline Montreal & Québec & 2018 & Montréal, ville inclusive & $4,318,505$ \\
\hline Edmonton & Alberta & 2018 & Access to municipal services without fear & $1,447,143$ \\
\hline London & Ontario & 2018 & Free of fear services for all policy & 545,441 \\
\hline Source: $(C a n d a, 2020)$ & &
\end{tabular}

Source: (Canada, 2020)

${ }^{a}$ According to the 2016 census, the total population of Ajax was 119,677 (Statistics Canada, 2017). Official population data for 2019 has yet to be released 
collection and processing. Cities usually also provide a variety of cultural and recreational facilities and services, including libraries, community centres, and parks. Some cities, and especially those that are larger, have been devolved some responsibility over health and social services, such as social housing and shelter provision, ambulances and long-term care, public health services, and immigration settlement services.

Second, these policies support state actions heavily geared toward providing information to potentially affected populations as well as informing and training city workers of the policy (Paquet et al., 2019). These policies also aim at clarifying - for the purpose of the administration and to the benefit of residents - the identification requirements for access to municipal services. Beyond explicit calls to remove barriers, several cities aim to realise this commitment through information campaigns and public awareness strategies. In some cases, such as Edmonton and Vancouver, policies also commit to reinforce existing policies on privacy and information collection. Toronto and Montreal stand as exception to this trend as they also provide funding to immigrant service groups to develop new interventions as part of their policies. Canadian sanctuary cities do not provide residents with municipal IDs or other forms of documentation. In general, thus, the implementation of sanctuary policies in Canada focuses more on clarifying access and procedures and less on the deployment of new services for residents.

Third, Canadian sanctuary policies do not apply to municipal and regional police forces or immigration enforcement activities (Hershkowitz et al., 2020; Hudson et al., 2017). This reflects the limited jurisdiction and powers of Canadian cities within the country's federal system, as compared to other levels of governments. Immigration enforcement is solely the responsibility of the federal government, whereas policing is enabled and regulated by provincial and federal authorities. Even when they have municipal police forces, Canadian cities have a finite capacity to control policing as legislation is provincial and municipalities cannot interfere in criminal investigations; though as funders of police services, they may have more room to intervene in policy-oriented issues (Sancton, 2015). As a result, cities cannot coerce police forces to change their policies or actions, including their decisions to enquire about immigration status. Similarly, Canadian sanctuary policies offer little or no guarantees that collaboration or communication on migration control matters between the police and federal enforcement authorities, such as the Canada Border Services Agency (CBSA), will stop on cities' territories. The rare research on police practices since the enactment of these policies shows no changes to police and enforcements practices of interagency information sharing about immigration status (Hershkowitz et al., 2020; Hudson et al., 2017; Moffette \& Gardner, 2015). Moreover, in the majority of Canadian sanctuary cities, police services have not issued a formal response to the access without fear policies. As such, Canadian sanctuary policies sadly offer limited protection from immigration enforcement to their residents.

The particularities of Canadian sanctuary policies demonstrate the importance of taking into account national differences when comparing these state activities. Canadian policies go beyond symbolic gesture and expand the realm of local 
government action to all residents, as opposed to all citizens. Yet, they are distinct from American policies that also include the delivery of identification documents and real changes to on-the-ground enforcement practices. Despite their limitations, however, these policies still offer support to non-status and precarious status residents by ensuring that they can have access to government services. As well, welcoming and non-criminalising local narratives are symbolically powerful for all city residents. In periods of heightened vulnerability and risks - such as the Covid-19 pandemic - these services can make a world of difference.

\subsection{Pandemic Risks for Non-status and Precarious Migrants in Canada}

The most visible risks faced by non-status and precarious migrants in Canada during the pandemic are related to access to healthcare. Public Health Insurance is free and available to Canadian citizens, permanent residents, and some temporary residents. Others must rely on expensive private insurance or, more often, live without insurance and pay out-of-pocket for treatment. ${ }^{2}$ Three provinces opened up access to at least Covid-19-related healthcare, regardless of immigration status: Ontario, Quebec, and British Columbia. These three jurisdictions are home to the three largest and most diverse cities in the country, which are all sanctuary cities: Toronto, Montreal, and Vancouver. At the time of writing (December 2020), British Columbia has withdrawn access to healthcare for all, while Quebec's policy is confined to Covid-19-related testing and care; any other healthcare, including medically necessary or life-threatening care, is not covered through the provincial health plan. Ontario remains the only province which has a policy of access to healthcare for all, regardless of immigration status. On 20 March 2020, the Ontario Ministry of Health announced it would cover the costs of 'all medically necessary' hospital services for uninsured clients, not limited to Covid-19 treatment (Hudson et al., 2020). ${ }^{3}$

Racial disparities among the Covid-19 infected population have been widely highlighted by both the recent body of literature and mass media, increasingly concerned by the disproportionate toll of the epidemic on communities of colour (Carrion et al., 2020; Chowkwanyun \& Reed, 2020) Canada makes no exception. Aggregated data released by local health authorities outline the spatial

\footnotetext{
${ }^{2}$ If one cannot pay up front, they will most of the time not be able to receive medical services, except in case of emergency (especially if a situation is deemed immediately life-threatening), even though the patient would be billed afterwards. There are some reports of non-status persons being detained and/or reported to the Canadian Border Service Agency while seeking healthcare (Gastaldo et al., 2012; Toronto, 2015). There are a handful of walk-in clinics in major cities like Toronto and Montreal that provide free primary care to uninsured migrants, but these count as a small fraction of clinics, and care does not include specialist care or diagnostics.

${ }^{3}$ The Ontario government also waived the three-month waiting period for returning Canadians and new immigrants so they could access provincial public health insurance immediately.
} 
concentrations of positive cases in low-income, racialised, and migrant-heavy areas of Canadian cities. Notably, Ontario's Public Health authority, exposed that its most ethno-culturally diverse neighbourhoods, located primarily in urban areas, are experiencing disproportionately higher rates of Covid-19 and related deaths (Public Health Ontario, 2020). More precisely, in Toronto, a correlation was found between high coronavirus rates and low income, low levels of education, and racialised populations, consequently hitting hardest the section of the town with larger Black populations (Bowden \& Cain, 2020). Similar findings were reported in Quebec, as Montréal-Nord, a prevailing neighbourhood for asylum seekers, became one of the crisis's epicentres (Shields \& Alrob, 2020) with the highest number of confirmed cases reported in the city, as well as the highest mortality rate as of September 2020 (Santé Montréal, 2020).

It comes to light that it isn't the density in terms of population in the affected neighbourhoods that influenced the case rate, but rather the density inside households. Housing overcrowding and consequent proximity has indeed proven to correlate with high Covid-19 infection rates (Almagro et al., 2020). With the increasingly high rents in Canadian urban areas, non-status migrants are among the most vulnerable to homelessness since their lack of status hinders their access to employment or alternative government support. They are often left with no choice but to settle for unsuitable housing without enough bedrooms for the occupants or rely on their social networks to obtain informal and, often, overcrowded housing (Paradis et al., 2008). Strikingly, it has been noted that immigrants and refugees tend to be under-represented in the Canadian emergency shelter system. This was found especially true for non-status migrants who worried about arrests and deportation if they accessed such organisations. Yet, the households providing hospitality significantly proved to do so while living in critical precarious situations themselves (Hiebert et al., 2005) As one would expect, these living situations make it impossible to socially distance or isolate, even from at-risk members of the household (Greenaway et al., 2020).

Another important factor leading to high pandemic vulnerability for these populations lies in mobility-based risk. Migrants were indeed highly represented in the low-paying essential service jobs which continued their activities during lockdowns, often in hazardous and crowded conditions (Flood et al., 2020; Greenaway et al., 2020). Notably, in Quebec, asylum seekers stood out during the crisis, as they volunteered to work on the frontlines in the Residential and Long-term Care Centres, (CHSLDs) where $92 \%$ of the Covid-related deaths were found (Dalexis \& Cénat, 2020). In the case of Toronto, the hardest-hit neighbourhoods were those where at least one-third of working residents commute to other wards and municipalities, including York region (which includes the lower-tier municipalities of Vaughan, Markham, Richmond Hill, Newmarket, and others). Thus, forced to commute to work while higher-income citizens experienced the privilege of remote occupations, non-status migrants exposed themselves to greater risk of infection, which they then brought back to overcrowded environments. Even when some essential workers were laid off, Covid-19 continued to spread due to the increased interactions in the households (Almagro et al., 2020). 
Non-status migrants and most precarious migrants are ineligible for income support programmes created in response to the pandemic, such as the Canadian Emergency Response Benefit (CERB) and for general government worker support. As a result, they have to continue working. The conditions in which non-status and precarious status migrants work is an important factor of risk to Covid-19 (Hennebry et al., 2020; Migrant Workers Alliance for Change, 2020). In Quebec, a survey of asylum seekers working in essential services such as hospitals, long-term care centres and the food service during the first Covid-19 wave, most of them living in Montreal, reported high infection rates, considerable issues accessing healthcare, and problems with employers' management of sick leave (Table de concertation des organismes au service des personnes réfugiées et immigrantes, 2020). Despite Montréal being a sanctuary city, these asylum seekers also reported having trouble accessing immigrant services and lacking information about supports offered by different governments (ibid.). It should be noted that when non-status migrants didn't occupy essential at-risk jobs, they were most likely to work in informal sectors of the economy (e.g. Norwegian Refugee Council, 2020) without any safety net when these were brought to a halt due to the pandemic.

However, the exacerbated risks non-status and precarious status migrants face during the sanitary crisis are not limited to the infection contingency. For instance, the closure of municipal and non-municipal services during the lockdown had considerable impact on the most vulnerable populations. First, research has drawn attention to the importance of libraries as a formal and informal information platform for migrants, acting as a meeting point (Caidi et al., 2010) and a community builder (Scott, 2011) as well as a provider of workshops, books, and computers (Aery \& Cheff, 2018). Libraries are often the only internet access available (Hall \& Wang, 2017), which is crucial for finding employment and housing or conducting regularisation processes. Other formal organisations, such as settlement agencies, community centres, ethno-cultural (Caidi et al., 2010) and non-profit organisations (Shields \& Alrob, 2020) also play an important role in migrants' lives. The crisis put these vital but already unstable and precariously-funded sectors under further strain. As their public-facing offices were forced to close and many had to reorient towards offering an online service, internet inaccessibility turned out to be a major obstacle to their use. The lockdown therefore compromised ingrained essential strategies, resources, and social networks for non-status migrants.

Raising awareness and imparting knowledge to the population on how to prevent the spread of Covid-19 was among the prioritised strategies in crisis mitigation. However, access to information was severely restricted for non-status migrants by the closures previously mentioned, but also by language barriers and unavailable adequate translations (Kluge et al., 2020). Undocumented migrants therefore could miss out on basic information about the pandemic and remain unaware of their eligibility to receive Covid-19 testing and treatment despite their lack of status.

As has been shown, the Covid-19 pandemic has highlighted and reinforced preexisting inequalities. An active government response was thus needed to ensure the protection of the most vulnerable populations throughout the public health crisis. In that sense, it could have been expected from sanctuary cities policies - given the 
nature of their objectives - to act as this required a safety net for migrants without status. Current evidence, however, is limited on the actual impact of these policies during the first waves of the pandemic. Part of this is due to the reality that Canadian cities' potential capacity to address the crisis was restricted by the scope of their jurisdictions and the scarce resources dedicated to their objectives. Indeed, while public health authorities have offices dedicated to specific cities, these are not typically part of municipal jurisdiction. In Canada, the healthcare system remains the provincial governments' responsibility and public health is co-managed by the federal and provincial governments. Only some cities, and to a limited extent, have authority over health and social services. In such cases, further investment in cityrun shelters and in the immigration settlements services' digitalisation could be undertaken. Fortunately, as mentioned above, some provinces - namely Ontario, Quebec, and British Columbia - have responded accordingly by extending the modalities of their healthcare to accommodate those without status for the duration of the crisis.

While there is no indication that the principles of sanctuary cities have been transgressed during the crisis, it goes without saying that policies ensuring access to municipal services have been rendered unenforceable by the lockdown. Sanctuary cities should take on the role of conveying vital information about the crisis to marginalised communities in appropriate translations, ensuring at the same time that non-status migrants are aware of provincial policies allowing them to be tested and treated without fear of deportation. Replacing urgent needs normally provided by municipal services, such as the internet connection offered by libraries, should also be among priorities.

Measures such as those described are possible avenues to mitigate pandemic risks faced by non-status migrants in Canadian cities. However, at the time of writing (December 2020), data are insufficient to confirm that any such particular initiatives were actually taken by Canadian sanctuary cities during the crisis. Other broader measures implemented by municipal governments, such as providing childcare for essential workers' children or reducing public transit fares, had, of course, a positive impact on non-status migrants by extension, but it appears that very little was systematically organised to meet their unique needs. Communities' agencies would have thus been left on their own to respond to emergency issues.

The Covid-19 pandemic poses acute risks for non-status and precarious migrants in Canada, like elsewhere in the world. At this point, the most impactful responses have come from provincial governments, in the form of policies providing improved access to health insurance and care. Canadian cities have implemented policies to support their residents in response to these events, but sanctuary policies have not been explicitly linked to these efforts. At the same time, despite operational and financial pressures, cities have not abolished their sanctuary policies. This means that sanctuary policies have the potential to expand in Canada but also highlights the need to provide cities with more capacities and resources in order to see this potential come to fruition. 


\subsection{Canadian Sanctuary Cities After COVID-19}

The aggravated risks implied for illegalised migrants during the sanitary crisis entail the urgent necessity of specific support from authorities. In that sense, one could expect sanctuary cities, particularly, to be responsive to their current needs. However, while urban initiatives have been implemented around the world to address the various vulnerabilities exacerbated by the pandemic, some specifically targeting the issues experienced by undocumented migrants, it is not known to date how many emergency initiatives were specifically related to sanctuary policies. In the US, Chicago notably, which identifies as a Sanctuary City, created an emergency fund, offering $1000 \$$ US per household excluded from the federal coronavirus relief payments, including undocumented residents (NBC Chicago, 2020). New Haven, which prohibited municipal officers from inquiring immigration status in 2006, reinforced their sanctuary policy during the pandemic, extending this prohibition to all city employees (McFadden, 2020). Other American disaster relief funds dedicated to undocumented migrants were rather attributed by States, such as California (Ho, 2020) and Washington State (Shapiro, 2020). Conversely, as one may anticipate, the crisis, also detrimentally affected sanctuary initiatives. For instance, the Canadian city of New Westminster suspended their work on the implementation of a new Sanctuary City policy in order to redirect the associated staff to an affordablehousing project (Mcmanus, 2020). While it didn't materialise, the then-President of the United States, Donald Trump, also threatened to condition coronavirus relief funds on compliance to federal immigration law (Burns, 2020). Both events raise concerns regarding the fragility of sanctuary policies, especially in times of crisis, when they are most needed.

The emergence of sanctuary policies in Canada was the result of years of activism, of social learning by city governments, and of strategic engagement with policy windows (Jeffries \& Ridgley, 2020; Moffette \& Ridgley, 2018). The large-scale social, political, and economic impacts of Covid-19 will generate new opportunities for Canadian cities' involvement in immigration-related matters while also potentially eroding the foundations of sanctuary policies. There is cause for concern that budding sanctuary policy development in Canada will be kyboshed if there is a return to austerity policy post-pandemic. At the same time, Covid-19 and its intersection with deep socio-economic divides have acted as a political disrupter challenging the neoliberal status quo. There is thus a policy window available for the pursuit of progressive change in the direction aligned with sanctuary cities. The importance of advocacy rises to the fore in the post-pandemic period. There will be struggles regarding the shape of the future. This will require migrant rights groups, settlement agencies and their umbrella support organisations, and other progressive forces to fight for a solidarity-based, more deeply institutionalised and scaled-up sanctuary movement directed at all levels of government in the future. This must be aligned with vigorous public advocacy for policies and programmes that support open multicultural societies, anti-racism, protection of the most vulnerable migrants, and robust social programmes that address structural inequality. This should be 
aligned with advocacy for improved municipal finance and more stable investment for the non-profit sector.

There is a need for sanctuary city activists to imagine what an ideal sanctuary city policy and administrative programme could look like in the Canadian context. Given provincial legislation that leaves local governments Canada-wide with different political systems and policy responsibilities as well as the great diversity of Canadian urban environments and populations, this will need to be a flexible policy agenda. Local governments across the board are in a difficult position in the Canadian landscape. They are closest to the population in the delivery of many frontline community and emergency services, often filling gaps or working with non-profit agencies to fill gaps. Yet, when these gaps become cavernous, local governments cannot cope with the demand because they have the least resources and jurisdictional responsibilities. Municipal finance has become additionally precarious during the pandemic as citizens without work struggle with property tax payments and user fees for services such as public transit have declined considerably. Supports for non-status residents become particularly at risk of falling by the wayside in this context. Municipal governments require additional resources from the provinces and the federal government to deliver crucial services. At the same time, the outrage over police brutality against Black, Indigenous, and people of colour (BIPOC) communities in cities has caused public interest in how municipalities are spending the limited tax dollars they have. Municipalities need a much better handle on by-law enforcement and policing and the practices of targeting BIPOC individuals and communities. These are policy issues that must be dealt with by the municipal council and in public.

The public scrutiny over municipal finance that has come from the call to defund the police is an important development away from an enforcement state and creates a policy window to fight for a retooled local government that properly invests in allocative programmes such as public transit, social housing, public health, and ample library and community programmes that meet the unique needs of different residents, including non-status migrants. Regarding non-status migrants' access to services, the pandemic has illustrated that the creation of municipal ID cards should be considered and that any closure of services should be done carefully with a plan for how the most vulnerable populations can continue to access crucial services. Municipal and non-profit frontline workers understand the important nature of their work for the populations they serve, who are often vulnerable. Local government should have assured a way to replace the services shut down by the pandemic. Emergency protocols to get services to vulnerable populations are needed in the future. Particular attention should have been paid to the transmission of information, including accessible translations and targeted locations.

Local governments need, in their urban planning, to understand the service and support needs of distinct population groups in different neighbourhoods. In other words, cities need to undertake social planning much more diligently and systematically so that neighbourhoods, apartment buildings, and populations with vulnerable residents can receive targeted supports and outreach. This relates to how local governments need to have a better handle on the nature and practice of precarious work 
and the lives and needs of those workers in terms of how they move around and live in the city and of their health risks and needs. While they were not without status, temporary farmworkers and other essential workers have been hit very hard by the pandemic. The conditions of work should have been inspected to assure their protection, extra measures should have been put in place to prevent their exploitation, and they should have been prioritised to receive proper testing and treatment. This speaks to the growing and important role of local governments in public health information and provision. Local governments require extra public health support and funding for prevention and to address crises based on the characters of their populations. Furthermore, the crisis has illustrated that local governments need to invest in better city-run shelters and in the coordination of these shelters in emergency scenarios. Extra measures should have been taken to address homelessness and precarious housing, and local governments need more money to invest in the provision of social housing.

We can see from the above pandemic reflections that sanctuary city policies must be widespread to include all local government departments and agencies working together. These programmes must be institutionalised across departments and agencies, through perhaps a central office that is staffed and funded and situated within the city managers' office, as well as incorporating dedicated staff and funding lines in each department and agency. Sanctuary policies must be consistently monitored and evaluated and should include emergency protocols for public health and climate crises. There is a need for a better collaboration between the provinces, municipalities, and the federal government regarding policy alignment and funding on the provision of status, healthcare, income support, social and emergency housing, public transit investment, and employment supports.

Moreover, the state needs to work (in an equitable fashion) with other actors in society, and in particular with non-profit sector service providers who provide the reach into communities where need is greatest. The states, including sanctuary cities, are dependent upon the non-profit sector to provide core services and supports to the public, including vulnerable migrant populations. Non-profits have in fact become even more important in recent decades as the neoliberal state has retreated from social welfare supports and turned to the non-profit sector to do ever more with less state financial assistance (Lowe et al., 2017). Non-profits act as less expensive, lean third social support systems and as 'society's shock absorbers when a crisis hits' (Speer \& Dijkema, 2020). Non-profit service organisations are needed more than ever to address human needs, but non-profit providers are themselves in crisis due to capacity challenges, declining donations and volunteer labour, revenue loss, and instability intensified by the pandemic (The Philantropist, 2020). They may be so weakened and under-supported that they will not be in a position to provide the necessary levels of support going into the future.

A case in point are food banks as organisations that provide a lifeline to the most marginalised in society. The pandemic resulted in enormous increases in demand for their services just as their capacity was diminished by the crisis (Fox, 2020). The non-profit settlement service sector has also been central in offering supports for vulnerable migrants, including housing and legal assistance, language instruction, 
employment supports, and counselling, among others, generally offered with the funding support of government, including sanctuary cities (Praznik \& Shields, 2018). As community-centred organisations, settlement agencies have been built as hands-on public-facing agencies. A large share of settlement workers are immigrants and direct contact with clients is an important part of the settlement service model (Praznik \& Shields, 2018). The pandemic has profoundly affected the ability of the settlement sector to deliver such services, pushing the settlement sector to be resilient and shapeshift into at-distance digital modes as public-facing offices were forced to close. The shuttering of most settlement agency offices during the pandemic was particularly difficult for the most vulnerable as they were the least able to access digital services.

\subsection{Concluding Remarks}

In this chapter, we have explored whether and how city sanctuary policies have responded to the Covid-19-related risks faced by non-status and precarious migrants. In doing so, we have described the specificities and limitations of sanctuary policies in Canada; as opposed to American sanctuary policies, Canadian policies are focused on access to existing services and information. They also have limited impact on immigration enforcement and offer no direct protection to non-status and precarious migrants besides assurance that municipal governments will not collect or store information about immigration status. These specificities are not the result of particular ideologies of city governments but instead reflect the particular position of Canadian cities in Canada's federal regime and their limited resources for action.

In Canada, non-status and precarious migrants have faced particular risks and have experienced increased vulnerabilities during the pandemic. These include access to healthcare, unsafe working conditions, economic insecurity, inadequate housing, and limited information. While cities have implemented policies for all of their residents, none of the Canadian sanctuary cities have explicitly enacted policies responding to Covid-19 linked to sanctuary. Moreover, the most impactful responses for these populations have, to date, been deployed by provincial governments.

Within the jurisdictional spaces of Canadian cities, more can be done to support non-status and precarious migrants to face pandemic risks. Cities can start to achieve this by: ensuring continued access to the infrastructure that helps migrants gain access to information; working on housing through inspections and temporary support; providing services in multiple language and supporting immigrant-serving organisations. Looking into the future, this chapter points to the importance of maintaining pressure and momentum to ensure that Canadian sanctuary cities remain in place in the post-pandemic recovery but also gain increased capacities. Ultimately, the Covid-19 pandemic should serve to reinforce the primary role of local governments in attenuating risks for the most vulnerable populations (Bauder 
\& Godoy, 2020; Patuzzi, 2020). And, as with local governments elsewhere in the world, this crisis further highlights how these governments can innovate with limited resources and despite constraining jurisdictional structures.

\section{References}

Aery, A., \& Cheff, R. (2018). Sanctuary city: Opportunities for health equity. Wellesley Institute. Agustín, Ó. G., \& Jørgensen, M. B. (2019). Institutional solidarity: Barcelona as refuge city. In Ó. G. Agustín \& M. B. Jørgensen (Eds.), Solidarity and the 'refugee crisis' in Europe (pp. 97-117). Springer.

Almagro, M., Coven, J., Gupta, A., \& Orane-Hutchinson, A. (2020). Racial disparities in frontline workers and housing crowding during COVID-19: Evidence from geolocation data. Available at SSRN, 3695249.

Atak, I. (2019). Toronto's sanctuary city policy: Rationale and barriers. In J. Darling \& H. Bauder (Eds.), Sanctuary cities and urban struggles: Rescaling migration, citizenship and rights (pp. 105-130). Manchester University Press.

Atak, I. (forthcoming). 'A responsible and committed city': Montréal's sanctuary policy. In H. Sanders \& L. Faret (Eds.), Cities protecting migrants: Critical perspectives on urban sanctuary and hospitality in the Americas. Palgrave Macmillan.

Bagelman, J. (2013). Sanctuary: A politics of ease? Alternatives, 38(1), 49-62.

Bauder, H. (2017). Sanctuary cities: Policies and practices in international perspective. International Migration, 55(2), 174-187.

Bauder, H., \& Godoy, M. (2020). Upscaling migrant sanctuary and solidarity policies and practices in times of COVID-19. International Organization for Migration.

Bauder, H., \& Gonzalez, D. A. (2018). Municipal responses to 'illegality': Urban sanctuary across national contexts. Social Inclusion, 6(1), 124-134.

Bauder, H., \& Weisser, T. (2019). Solidarity cities in Germany and Switzerland: A brief overview of initiatives (RCIS research brief no. 2019/2). RCIS, Ryerson University.

Bowden, O., \& Cain, P. (2020). Black neighbourhoods in Toronto are hit hardest by COVID-19 And it's 'anchored in racism': Experts. Global News. https://globalnews.ca/news/7015522/ black-neighbourhoods-toronto-coronavirus-racism/. Accessed 2 June 2020.

Burns, K. (2020). Trump wants to use coronavirus aid as leverage to force blue states to change immigration policies. Vox, 28 April. www.vox.com

Caidi, N., Allard, D., \& Quirke, L. (2010). Information practices of immigrants. Annual Review of Information Science and Technology, 44(1), 491-531. https://doi.org/10.1002/ aris. 2010.1440440118

Canada. (2020). Table 17-10-0135-01 Population estimates, July 1, by census metropolitan area and census agglomeration, 2016 boundaries. https://doi.org/10.25318/1710013501-eng

Carrion, D., Colicino, E., Pedretti, N. F., Arfer, K. B., Rush, J., DeFelice, N., \& Just, A. C. (2020). Assessing capacity to social distance and neighborhood-level health disparities during the COVID-19 pandemic. medRxiv.

Chowkwanyun, M., \& Reed, A. L. (2020). Racial health disparities and Covid-19 - Caution and context. New England Journal of Medicine, 383(3), 201-203. https://doi.org/10.1056/ NEJMp2012910

City of London. (2018). Free of fear services for all policy.

Dalexis, R. D., \& Cénat, J. M. (2020). Asylum seekers working in Quebec (Canada) during the COVID-19 pandemic: Risk of deportation, and threats to physical and mental health. Psychiatry Research, 292, 113299. https://doi.org/10.1016/j.psychres.2020.113299

de Graauw, E. (2014). Municipal ID cards for undocumented immigrants: Local bureaucratic membership in a federal system. Politics and Society, 42(3), 309-330. 
Flood, C. M., MacDonnell, V., \& Philpott, J. (Eds.). (2020). Vulnerable: The law, policy and ethics of COVID-19. University of Ottawa Press.

Fox, C. (2020). Toronto food banks report 'worrisome' increase in use amid COVID-19 pandemic. CTV News. https://toronto.ctvnews.ca/ toronto-food-banks-report-worrisome-increase-in-use-amid-covid-19-pandemic-1.4887864

Gastaldo, D., Carrasco, C., \& Magalhaes, L. (2012). Entangled in a web of exploitation and solidarity: Latin American undocumented workers in the Greater Toronto Area. http://www.migrationhealth.ca/sites/default/files/Entangled_in_a_web_of_exploitation_and_solidarity_LQ.pdf

Goldring, L., Berinstein, C., \& Bernhard, J. K. (2009). Institutionalizing precarious migratory status in Canada. Citizenship Studies, 13(3), 239-265.

Goldring, L., \& Landolt, P. (2013). Producing and negotiating non-citizenship: Precarious legal status in Canada. University of Toronto Press.

Greenaway, C., Hargreaves, S., Barkati, S., Coyle, C. M., Gobbi, F., Veizis, A., \& Douglas, P. (2020). COVID-19: Exposing and addressing health disparities among ethnic minorities and migrants. Journal of Travel Medicine, 27(7). https://doi.org/10.1093/jtm/taaa113

Hall, J., \& Wang, S. (2017). Graham Hudson, Idil Atak, Michele Manocchi \& Charity-Ann Hannan RCIS Working Paper No. 2017/1 February 2017.

Hannan, C.-A., \& Bauder, H. (2015). Towards a sanctuary province: Policies, programs, and services for illegalized immigrants' equitable employment, social participation, and economic development (RCIS working paper). Ryerson Centre for Immigration and Settlement.

Hari, A. (2014). Temporariness, rights, and citizenship: The latest chapter in Canada's exclusionary migration and refugee history. Refuge: Canada's Journal on Refugees, 30(2), 35-44.

Hennebry, J., Caxaj, C. J, McLaughlin, J. E, \& Mayell, S. (2020). Coronavirus: Canada stigmatizes, jeopardizes essential migrant workers. The Conversation, 3 June. https://theconversation. com/coronavirus-canada-stigmatizes-jeopardizes-essential-migrant-workers-138879

Hershkowitz, M., Hudson, G., \& Bauder, H. (2020). Rescaling the Sanctuary City: Police and nonstatus migrants in Ontario, Canada. International Migration, 59(1), 38-57.

Hiebert, D., Addario, S., \& Sherrell, K. (2005). The profile of absolute and relative homelessness among immigrants, refugees, and refugee claimants in the GVRD final report. https:// www.mosaicbc.org/wp-content/uploads/2017/01/The-Profile-of-Absoluteand-RelativeHomelessness.pdf

Ho, V. (2020). California launches nation's first disaster relief fund for undocumented immigrants. The Guardian, July 24, 2020.

Hudson, G., Atak, I., Manocchi, M., \& Hannan, C.-A. (2017). (No) access T.O.: A pilot study on sanctuary city policy in Toronto, Canada. RCIS Working Paper.

Hudson, G., Cébron, C., \& Mallette, R. L. (2020). Access to health care for precarious and nonstatus migrants during COVID-19: Ontario and Québec. Canadian Diversity, 17(3), 45-49.

International Organization for Migration. (2019). World migration report 2020. International Organization for Migration.

Jeffries, F., \& Ridgley, J. (2020). Building the sanctuary city from the ground up: Abolitionist solidarity and transformative reform. Citizenship Studies, 24(4), 548-567.

Kluge, H. H. P., Jakab, Z., Bartovic, J., D’Anna, V., \& Severoni, S. (2020). Refugee and migrant health in the COVID-19 response. The Lancet, 395(10232), 1237-1239. https://doi. org/10.1016/S0140-6736(20)30791-1

Lippert, R. (2004). Sanctuary practices, rationalities, and sovereignties. Alternatives, 29(5), 535-555.

Lowe, S., Richmond, T., \& Shields, J. (2017). Settling on austerity: ISAs, immigrant communities and neoliberal restructuring. Alternate Routes: A Journal of Critical Social Research, 28(2017), 14-46.

Lowry, M., \& Nyers, P. (2013). No one is illegal: The fight for refugee and migrant rights in Canada. Refuge: Canada's Journal on Refugees, 21(3), 66-72. 
Martínez, D. E., Martínez-Schuldt, R. D., \& Cantor, G. (2018). Providing sanctuary or fostering crime? A review of the research on 'sanctuary cities' and crime. Sociology Compass, 12(1), e12547. https://doi.org/10.1111/soc4.12547

McDonald, J. (2009). Migrant illegality, nation building, and the politics of regularization in Canada. Refuge: Canada's Journal on Refugees, 26(2), 65-77.

McFadden, M. (2020). Mayor signs 'welcoming city' order to protect immigrant rights. New Haven Independent, 15 April.

Mcmanus, T. (2020). New Westminster approves expedited process for affordable housing project in Queensborough. New Westminster Record, 12 August.

Migrant Workers Alliance for Change. (2020). Report: Unheeded warnings - COVID-19 \& migrant workers in Canada. https://migrantworkersalliance.org/wp-content/uploads/2020/06/ Unheeded-Warnings-COVID19-and-Migrant-Workers.pdf

Moffette, D., \& Gardner, K. (2015). Often asking, always telling: The Toronto Police Service and the sanctuary city policy. No One is Illegal Toronto. http://rabble.ca/sites/rabble/files/often asking_always_telling_-_kedits_dec_1.pdf

Moffette, D., \& Ridgley, J. (2018). Sanctuary city organizing in Canada: From hospitality to solidarity. Migration and Society, 1(1), 147-155.

Morris, M. (2020). Sanctuary cities? How regional mayors can protect victims of crime with insecure immigration status. Institute for Public Policy Research.

Nail, T., Kamal, F., \& Hussan, S. (2010). Building sanctuary city: NOII-Toronto on non-status migrant justice organizing. Upping the Anti, 11, 149-162.

NBC Chicago. (2020). Chicago announces fund to pay undocumented immigrants, others left out of federal coronavirus relief. NBC Chicago, 10 June.

Norwegian Refugee Council. (2020). Downward Spiral: The economic impact of COVID-19 on refugees and displaced people. NRC.

Nyers, P. (2010). No one is illegal between city and nation. Studies in Social Justice, 4(2), 127-143.

O'Brien, B. G., Collingwood, L., \& El-Khatib, S. O. (2019). The politics of refuge: Sanctuary cities, crime, and undocumented immigration. Urban Affairs Review, 55(1), 3-40. https://doi. org/10.1177/1078087417704974

Paquet, M. (2017). Aux États-Unis, des villes sanctuaires. Plein droit, 115(Décembre), 11-14.

Paquet, M., \& Larios, L. (2018). Venue shopping and legitimacy: Making sense of Harper's immigration record. Canadian Journal of Political Science, 51(First view), 817-836.

Paquet, M., Dickins, G., Bruneau, C., Atak, I., \& Hudson, G. (2019). Mandat d'étude comparative 'Villes "sanctuaires" au Canada'. Report prepared for the City of Montréal.

Paradis, E., Novac, S., Sarty, M., \& David Hulchanski, J. (2008). Better off in a shelter? A year of homelessness \& housing among status immigrant, non-status migrant, \& Canadian-born families (Research paper 213). University of Toronto.

Patuzzi, L. (2020). Driving migrant inclusion through social innovation. In Lessons for cities in a pandemic. Migration Policy Institute Europe and International Organization for Migration.

Praznik, J., \& Shields, J. (2018). An anatomy of settlement services in Canada: A guide. Ryerson University.

Provine, D. M., \& Varsanyi, M. W. (2012). Scaled down: Perspectives on state and local creation and enforcement of immigration law introduction to the special issue of law \& policy. Law \& Policy, 34(2), 105-112.

Public Health Ontario. (2020). COVID-19 in Ontario - A focus on diversity.

Ridgley, J. (2008). Cities of refuge: Immigration enforcement, police, and the insurgent genealogies of citizenship in US sanctuary cities. Urban Geography, 29(1), 53-77.

Sancton, A. (2015). Canadian local government: An urban perspective (2nd. ed.). Oxford University Press.

Santé Montréal. (2020). Situation of the coronavirus (COVID-19) in montreal. https://santemontreal.qc.ca/en/public/coronavirus-covid-19/situation-of-the-coronavirus-covid-19-in-montreal/

Scott, R. (2011). The role of public libraries in community building. Public Library Quarterly, 30(3), 191-227. https://doi.org/10.1080/01616846.2011.599283 
Shapiro, N. (2020). Governor creates $\$ 40$ million relief fund for undocumented immigrants. The Seattle Times, 11 August.

Shields, J., \& Alrob, Z. A. (2020). COVID-19, migration and the Canadian immigration. System. Speer, S., \&Dijkema, B. (2020). Charities need government support as demands rise for their services. Policy Options. https://policyoptions.irpp.org/magazines/march-2020/ charities-need-government-support-as-demands-rise-for-their-services/

Statistics Canada. (2017). Ajax, T [Census subdivision], Ontario and Ontario [Province] (table). Census Profile. 2016 Census. Statistics Canada Catalogue no. 98-316-X2016001. https:// www12.statcan.gc.ca/census-recensement/2016/dp-pd/prof/index.cfm?Lang=E

The Philantropist. (2020). How crisis breeds innovation and making the case for policy overhauls. Sector News Digest, 21 April.

Table de concertation des organismes au service des personnes réfugiées et immigrantes. (2020). Demandeurs d'asile travaillant dans les services essentiels: près de 400 témoignages. https:// tcri.qc.ca/images/publications/memoires/2020/Rapport_de_recherche_DA_travaillant_dans_ les_services_essentiels_TCRI.pdf

Toronto. (2015). Access to city services for undocumented torontonians: Progress of the access T.O. initiative.

Tungohan, E., Banerjee, R., Chu, W., Cleto, P., de Leon, C., Garcia, M., Kelly, P., Luciano, M., Palmaria, C., \& Sorio, C. (2015). After the live-in caregiver program: Filipina caregivers' experiences of graduated and uneven citizenship. Canadian Ethnic Studies, 47(1), 87-105.

Varsanyi, M. W. (2006). Interrogating 'urban citizenship' vis-à-vis undocumented migration. Citizenship Studies, 10(2), 229-249.

Varsanyi, M. W., Lewis, P. G., Provine, D., \& Decker, S. (2012). A multilayered jurisdictional patchwork: Immigration federalism in the United States. Law \& Policy, 34(2), 138-158.

Wong, T. K. (2017). The effects of sanctuary policies on crime and the economy. Center for American Progress.

Young, J. E. E. (2011). 'A new politics of the city': Locating the limits of hospitality and practicing the city-as-refuge. ACME: An International Journal for Critical Geographies, 10(3), 534-563.

Young, J. E. E. (2012). Seeking sanctuary in a border city: Sanctuary movement (s) across the Canada-US border. In Sanctuary practices in international perspectives (pp. 250-262). Routledge.

Open Access This chapter is licensed under the terms of the Creative Commons Attribution 4.0 International License (http://creativecommons.org/licenses/by/4.0/), which permits use, sharing, adaptation, distribution and reproduction in any medium or format, as long as you give appropriate credit to the original author(s) and the source, provide a link to the Creative Commons license and indicate if changes were made.

The images or other third party material in this chapter are included in the chapter's Creative Commons license, unless indicated otherwise in a credit line to the material. If material is not included in the chapter's Creative Commons license and your intended use is not permitted by statutory regulation or exceeds the permitted use, you will need to obtain permission directly from the copyright holder.

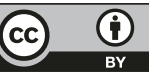

